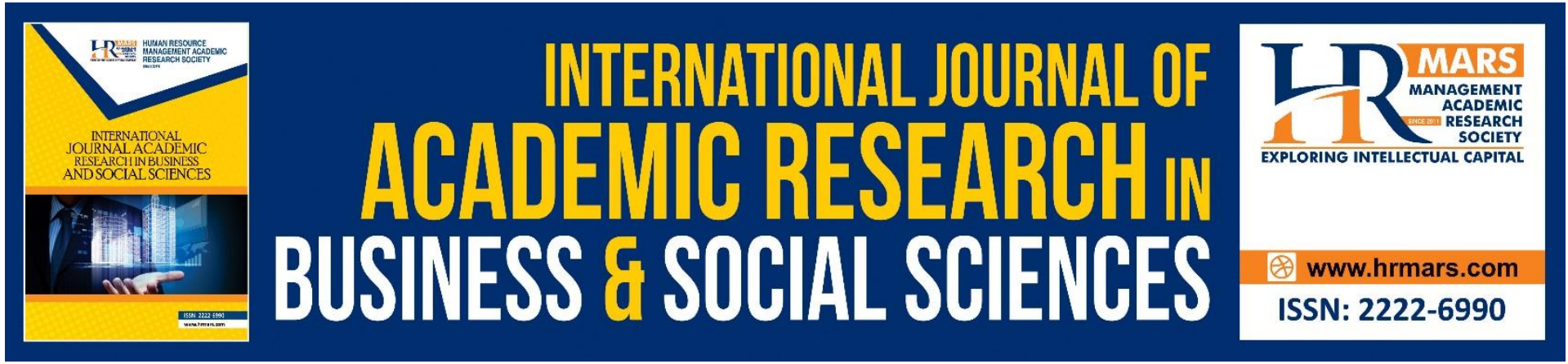

\title{
Rebuilding Crisis Response Strategies: Nigerian University Reputation Sustainability during and after the Covid-19 Pandemic Crisis
}

Egede Dominion Dominic, Mastura Mahamed, Zulhamri Abdullah, Norliana Binti Hashim

To Link this Article: http://dx.doi.org/10.6007/IJARBSS/v11-i6/10371 DOI:10.6007/IJARBSS/v11-i6/10371

Received: 25 April 2021, Revised: 29 May 2021, Accepted: 14 June 2021

Published Online: 27 June 2021

In-Text Citation: (Dominic et al., 2021)

To Cite this Article: Dominic, E. D., Mahamed, M., Abdullah, Z., \& Hashim, N. B. (2021). Rebuilding Crisis Response Strategies: Nigerian University Reputation Sustainability during and after the Covid-19 Pandemic Crisis. International Journal of Academic Research in Business and Social Sciences, 11(6), 1448-1466.

Copyright: (c) 2021 The Author(s)

Published by Human Resource Management Academic Research Society (www.hrmars.com) This article is published under the Creative Commons Attribution (CC BY 4.0) license. Anyone may reproduce, distribute, translate and create derivative works of this article (for both commercial and non-commercial purposes), subject to full attribution to the original publication and authors. The full terms of this license may be seen at: http://creativecommons.org/licences/by/4.0/legalcode

Vol. 11, No. 6, 2021, Pg. 1448 - 1466

Full Terms \& Conditions of access and use can be found at http://hrmars.com/index.php/pages/detail/publication-ethics 


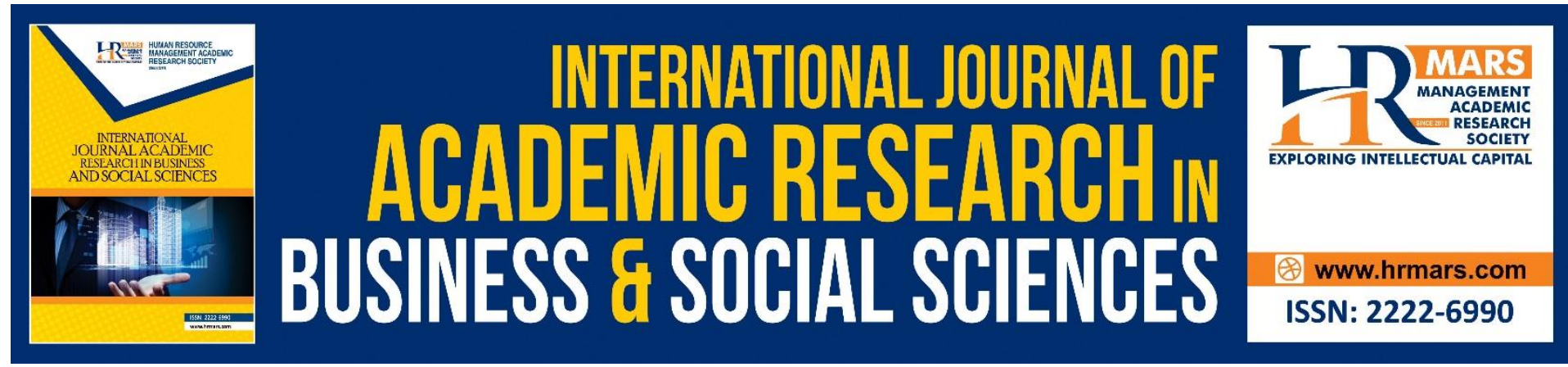

\title{
Rebuilding Crisis Response Strategies: Nigerian University Reputation Sustainability during and after the Covid-19 Pandemic Crisis
}

\author{
Egede Dominion Dominic, Dr. Mastura Mahamed, Assoc. Prof. \\ Dr. Zulhamri Abdullah, Dr. Norliana Binti Hashim \\ Faculty of Modern Languages and Communication, Universiti Putra Malaysia 43400 UPM \\ Serdang Selangor Darul Ehsan MALAYSIA \\ Email:dominicegededominion@gmail.com,mastura.mahamed@upm.edu.my, \\ zulhamri@upm.edu.my,h_norliana@upm.edu.my
}

\begin{abstract}
Purpose: The outbreak of the 2019 novel coronavirus (COVID-19) is projected to have severe potential threats to university reputation. This paper aims to examine how rebuilding crisis response strategies (RCRS) will protect and sustain the university's reputations during and after emerging outbreaks of pandemic crises in the Nigerian context.

Design/methodology/approach: This review paper is on the synthesis of university covid-19 related news, supported by relevant literature review on Covid-19 and university reputation, and the strength of Situational Crisis Communication Theory's (SCCT) rebuilding response strategies. However, the authors' personal experiences in investigating the trends on pandemic crises and university reputation sustainability also contributed to the study.

Findings: This paper predicts that epidemics and pandemics have a potential impact on university reputation, thus, affecting good stakeholders' relationships, positive marketization, smooth functionalization, and favorable working environments. Rebuilding response strategies have the power to protect and rebuild universities' reputations during and after a pandemic crisis. Therefore, rebuilding strategies should be considered by university bodies for reputational sustainability during and after a pandemic crisis in the Nigerian context.

Research limitations/implications: This review is limited to the pandemic crisis and its response strategies among Nigerian universities. While Nigerian universities reflect upon how to bring positive changes in terms of university-industry reputation following this Covid-19 pandemic, subsequent research should also consider the best possible crisis response strategy among universities to mitigate the effects of similar future pandemics crises, looking at other geographical contexts.

Practical implications: This review paper serves as recommendations for Nigerian universities and policymakers, focusing on reputation sustainability during a pandemic crisis. The suggestions may help in the alleviation of and fight against an emerging pandemic-related outbreak, offers university bodies a newly enriching pandemic response strategy, and partially if not completely mitigate the impact of COVID-19 on the university's reputation.
\end{abstract}


These recommendations can also be applied more broadly to global Higher Education Institutions.

Social implications: Socially, the COVID-19 outbreak has indeed brought significant impacts on society and organizations globally. Academic crisis communication scholars and practitioners should carefully consider this rebuilding response strategy and how it sustains social practices. Therefore, this response strategy should be viewed holistically in terms of its effects in minimizing pandemic crises on the social environments, climates, and among universities' stakeholders themselves.

Originality/value: This paper represents the first study of its kind, critically examining the impacts of the COVID-19 pandemic crisis on Nigerian Universities and how rebuilding response strategy projections possibly minimize the reputational threats, sustain the reputation and protect stakeholder expectations during a pandemic crisis as covid-19 and other future pandemic related outbreaks.

Keywords: Covid-19, Rebuilding Crisis Response Strategy (RCRS), University Reputation Suitability (URS) and COVID-19 Pandemic

\section{Introduction}

No organization is free from crisis and a pandemic crisis is complex and difficult to deal with. Hence, it has affected organizational reputation globally. Pandemics such as severe acute respiratory syndrome SARS, 2003; coronavirus19 COVID-19, 2019 and other related pandemics are comparatively uncontrollable when they emerge suddenly. Reputation is a multidimensional construct that is dynamically unstable and changes over time (Kim, Kim, \& Rhee, 2021). In definition, it is the organizational asset, a reservoir of organizations' prestige and image protecting organizations during a crisis situation. Most importantly, reputation enhances organizational market value (Dowling, 2006), and the validity of every organization in times of crisis depends on its reputation (Alshami, 2021). A pandemic as COVID-19 generated interrelated organizational challenges that threatened the university organization's reputation and stakeholders' relationships. Pandemics are large-scale infectious disease outbreaks with increased morbidity and mortality rate, happening over a wide geographic area. Pandemic causes significant social, economic, academic, and political disruptions (Madhav, Oppenheim, et al., 2017).

However, crisis response strategies imply the communication and responses employed by organizations in a challenging crisis. Simply put, what an organization does or says during a crisis is its crisis response strategies. Rebuilding crisis response strategies according to the Coombs, Situational Crisis Communication Theory SCCT, (2007) includes using compensation, apology, and taking complete measures responsibilities to improve the organization's reputation during and after a crisis. Rebuilding response strategies generate new reputational assets (Randiek, 2019). Rebuilding strategy in the form of apology and compensation effectively sustains reputation and rebuilds stakeholders' credibility during crises (Huang \& DiStaso, 2020). The purpose of this study is to demystify a framework, using rebuilding crisis response strategies in the form of compensation and apology to protect university reputations during pandemics crises.

\section{Covid-19 Pandemic}

The recent outbreak of the Covid-19 pandemic crisis has exposed lapses in the universities' unpreparedness for the pandemic crisis. For this reason, it has equally affected universities' reputations and posed a threat to stakeholders' relationships (Tesar, 2020). Over 30 years 
ago, pandemics kept reoccurring and having a potential impact on organizational reputations. For example, American polio epidemic: 1916, Spanish Flu: 1918, Asian flu: 1957, HIV/AIDS pandemic: 1981, SARS; 2003, H1N1 Swine Flu pandemic, 2009, West African Ebola epidemic: 2014, Zika Virus epidemic: 2015, covid-19; 2019 (Morse \& Schluederberg, 1990; Gates, 2015). These reemerging pandemics should have been enough for universities to increase readiness to combat Covid-19, but the reverse is the case (Reperant \& Osterhaus, 2017; Ryu, 2017), quoted by Shamsir (2021). Thus, universities globally need to evaluate current pandemic crisis plans and modify them to address the emerging pandemic crisis (Gainey, 2010).

A review of past studies on pandemics crises indicated no pandemic crisis response strategies in place by university institutions globally towards upholding university reputation sustainability during a pandemic crisis. For example, a study in Hong Kong on Severe Acute Respiratory Syndrome (SARS) 2003 showed no response in place by the university to address the crisis and restore reputation. The study has 215 students sample size ( $\mathrm{Yu}, \mathrm{Li}, \mathrm{Wong}$, et al., 2004). Another study in China on Hemorrhagic fever with renal syndrome (HFRS) 2006 confirmed, no university pandemic crisis response strategies in place to address the pandemic crisis (Zhang et al., 2009). Furthermore, in the USA, a study on flu outbreaks in Southeast Asia affecting University of Washington (UW) operations 2009, with a sample size of 50 university administrators, revealed the absence of university pandemic plans in place to combat the pandemic crisis and protect reputation (Beaton et al., 2007). Again, in Korea, Australia, UK, Turkey, India, Egypt, and Japan studies were conducted on H1N1 2009 with students' population. However, no emphasis on university pandemic crisis response strategies, to curtail the impact of the pandemic crises and protect reputation (Choi \& Yang 2010; Seale et al., 2012; Arinaminpathy et al., 2012; Akan, 2010; Suresh et al., 2011; Kamal \& Seedhom, 2011; Uchida et al., 2012).

Again, in Canada, a study conducted with a 357 students sample size on Norovirus 2009 also found no university pandemic response strategy in place (Surgeoner et al., 2009). In Malaysia and Pakistan, studies on the Ebola 2015 pandemic called for an immediate need to raise awareness among the university population with emphases on the relevance of university pandemic response strategies and reputation sustainability during a pandemic crisis (Etokidem et al., 2018; Salman et al., 2017). In Saudi Arabia, another study on the Middle East respiratory syndrome (MERS 2018) among universities and there was no emphasis on pandemic response strategies found in the study (Tork \& Mersal, 2018). In Nigeria, a study conducted on the COVID-19 pandemic crisis showed that the COVID-19 outbreak disrupted university education, most especially on the public universities with at least 290.5 million student's disruptions thus, threatening university reputation (Ozili \& Arun, 2020). According to Koonin (2020), now is the time to refresh university pandemic crisis response strategies and sustain reputation during pandemic situations.

Therefore, Covid-19 has exposed, and or reduced the universities' environment to dangergrounds. According to The United Nations Educational, Scientific, and Cultural Organization (UNESCO, 2020), over 900 million students were affected (Setiawan, 2020). In China and Hong Kong, $84 \%$ of university students were affected by Covid-19 (Mok, Xiong, Ke, \& Cheung, 2021). In the UK, USA, and Australia, the study found a $90 \%$ decrease in university intake due to the Covid-19 pandemic (Martel, 2020; Mercado, 2020). African universities suffered the Covid-19 pandemic by $40 \%$ (Jain, Budlender, Zizzamia, \& Bassier, 2020; Aborode, Anifowoshe, Ayodele, Iretiayo, \& David, 2020). In Nigeria, Covid-19 impacted universities by $94 \%$ (Chukwuorji \& lorfa, 2020; Oyediran, Omoare, Owoyemi, Adejobi \& Fasasi, 2020). Malaysian universities are 
not exceptional as the pandemic caused psychological impact and anxieties among universities' students (Sundarasen et al., 2020).

Consequently, a study conducted in Nigeria on the African universities' response to HIV/AIDS showed that African universities do not have crisis response strategies in place for pandemic crisis despite the potential impact it has on university reputation. (Katjavivi \& Otaala, 2003). However, it is alarming that up to recently universities had done very little in respect to investigating an effective appropriate pandemic crisis response strategy (Kelly, 2001). A study in Malaysia affirmed Kelly's findings that there is still a lack of communication response strategies by university organizations to protect reputation, integrity, continuity, and future existence during a pandemic crisis (Shamsir, Krauss, et al., 2021). Again, a study conducted in the USA affirmed that response to the pandemic crisis has not been examined especially among university organizations (Koonin, 2020). Therefore, it is most paramount for immediate pandemic crisis response strategic plans to be put in place to protect university reputation during the COVID-19 crisis and other related future pandemic crises. In the attempt to fill this gap, this review of the literature was conducted and rebuilding crisis response strategy RCRS suggested.

\section{Rebuilding Crisis Response Strategy (RCRS) Rationale and Reputational Sustainability.}

Reputation is crucial, and if allowed to be damaged could result in organizational extinction. Till now, the Nigerian university's traditional pedagogical approach has been downtrodden as a result of inadequate funding, frequent strikes actions, decline in the quality of research, lack of ICT integration in the university system, inadequate infrastructural facilities, insecurity, and cultism, and political interferences among public universities. Unfortunately, the outbreak of the COVID-19 pandemic exposed and heightened the existing situation, posing a potential threat to Nigerian Public University Reputation NPUR (Abugre, 2018; Nwagwu, 2020).

Consequently, there is a need for compensation and apology to be administered by both the university organizations and the Nigerian government to the relevant stakeholders. Based on the characteristics of RCRS, this can materialize through school fees discount, provision of learning facilities to meet the current academic challenges, and re-establishment of trust, credibility, positive stakeholder relationships, and smooth performativity to restore NPUR. During severe crises as pandemics, caring for the stakeholders' expectations restore the reputation-this is what rebuilding crisis response strategy does (Huang \& DiStaso, 2020; Coombs, 2007; Randiek, 2019; Ou \& Wong, 2020; Kriyantono \& McKenna, 2019).

Stakeholders always are perceived as being influential and a significant facet towards reputational sustainability during a crisis. Therefore, a response strategy that puts stakeholders at its top priority is paramount during a pandemic crisis. Organizational reputation considers the relationship between stakeholders and organization image in performativity, interactivity, and dynamic standpoint (Aladwan \& Alshami, 2021). Scholars found that during a pandemic crisis, stakeholders prefer organizations with their interests at heart mostly. Thus, RCRS is necessary to rebuild stakeholders' credibility and sustain reputation in times of pandemic crises, and it is fit for an emergency that presents a severe reputational threat (Huang \& DiStaso, 2020). Crisis communication scholars posited that RCRS generates the most effective reputational restoration during a crisis (Seeger \& Ulmer, 2002; Ye \& Ki, 2017; Randiek, 2019; Schoofs et al., 2019; Coombs, Holladay, \& White, 2020).

When a pandemic crisis hits, organizations with a strong reputational capital tend to survive more, compared with a struggling and weak organizational reputation capital. In Nigeria's 
context, university (organizations) reputation is still struggling with many deficiencies and therefore, remain in a deplorable ranking position in measuring with western universities. However, due to the poor conditions that surround Nigeria universities, stakeholders play a vital role in reputational judgment during severe crises. To this effect, accommodative crisis response strategies that prioritize stakeholders' interest and build the publics' confidence during serious pandemic crises, should be employed to sustain reputation (Gwebu, Wang, \& Wang, 2018). Rebuilding crisis response strategies RCRS in the form of compensation and apology maintain stakeholders' relationships, sustain the reputation and create a positive publics' perception for organizations during a severe crisis irrespective of the type of crisis and crisis responsibility (Ou, \& Wong, 2020; Kriyantono, \& McKenna, 2019).

Based on the reviewed literature, in examining the interplay of crisis response strategies and reputational sustainability, stakeholders prefer rebuilding crisis response strategies during severe crises (Kiambi \& Shafer, 2016). Consequently, pandemics crises impact a university's reputation and cause reputational threats along with negative public perceptions. In response, RCRS maintains stakeholders' relationships, sustains reputation, and establishes positive public perceptions. Hence, this makes RCRS more appropriate among other SCCT's response strategies, as universities respond to pandemic crises. Responding to the previous findings, RCRS is recommended in other to sustain the reputation and maintain stakeholders' relationships among Nigeria universities, alongside positive publics' perception during pandemics crises.

However, from the review of past studies also, the authors arrived at the study diagram and key insights: Impacts of COVID=19 on Nigeria university organizational reputation and the protective strength of rebuilding crisis response strategies. Despite Nigerian universities have been affected negatively due to the sudden outbreak of the Covid-19 pandemic crisis and previous pandemics and epidemics crises (Jacob, Abigeal, et al., 2020) study still found a lack in the pandemic crisis response strategy to fight these infectious diseases and protect university reputation as well as keeping positive relationships with stakeholders. Nigeria still operates a vertical approach to pandemics crisis with no emphasis on university pandemic crisis response and strategic plan to ensure continuity and maintain a positive reputation (Ilesanmi, \& Afolabi, 2020). This review predicts RCRS as the most appropriate in meeting stakeholders' expectations and protecting Nigerian university reputations during a pandemic crisis (Im, Youk, \& Park, 2021). 


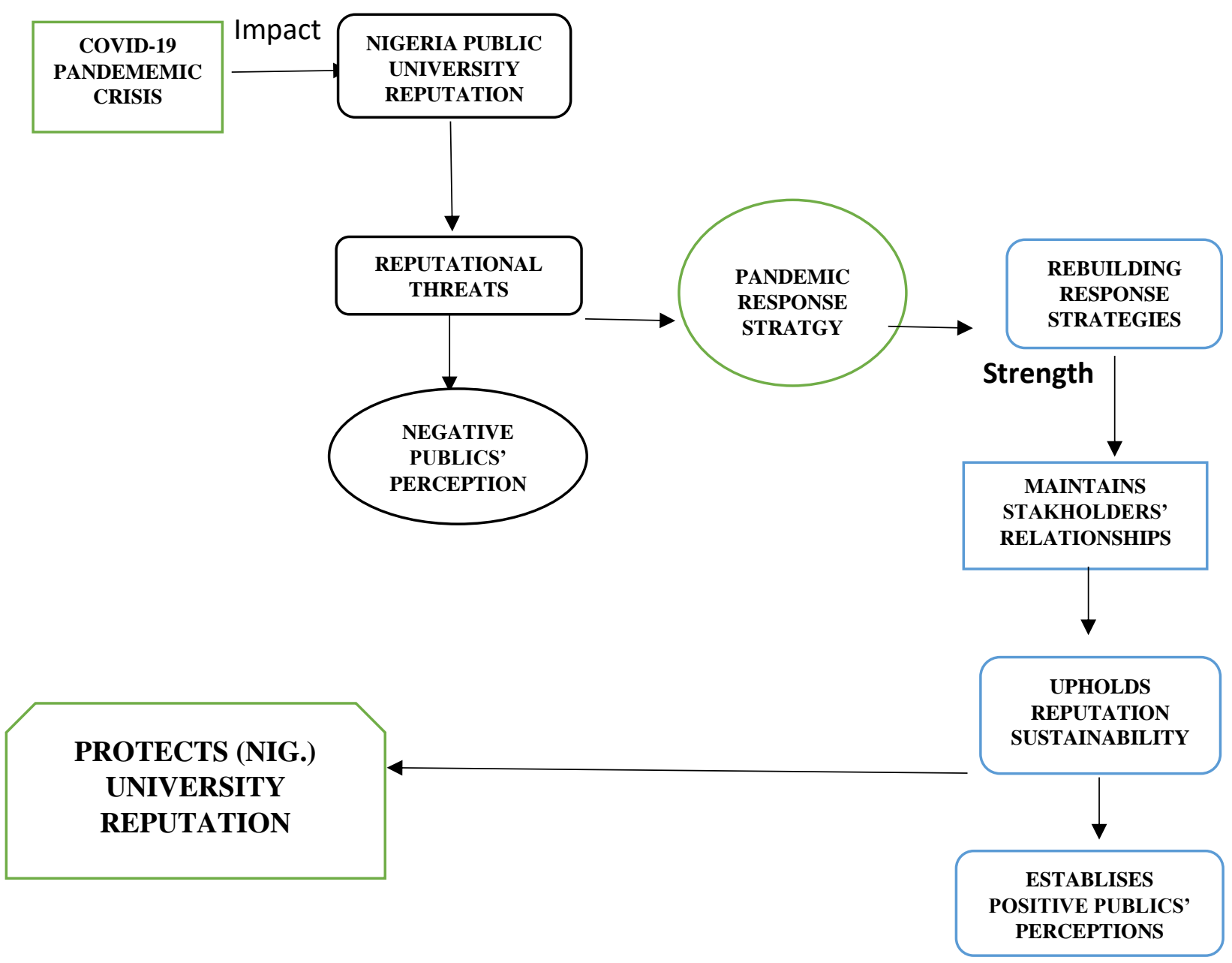

Figure 1: Study diagram and key insights: Impacts of COVID-19 on Nigeria university organizational reputation and the protective strength of Rebuilding crisis response strategies.

\section{Key Domains for Rebuilding Crisis Response Strategies (RCRS)}

Again, this literature review identified four (the 4 Cs) important domains for Rebuilding Crisis Response Strategies (RCRS) planning among universities facing pandemic crises. However, these domains are significant in mitigating any pandemic severity, protect organizational continuity, and promote reputational sustainability during pandemic crises among university organizations. These crucial domains include planning for university organizations' continuity, protecting organization crew (university workforce), caring for the customers (stakeholders), and positive engagements with the community (government and organizational locality). The relevance of RCRS is to prioritize these key domains thus, guarantee reputational sustainability during a severe pandemic crisis (Li, Wei, \& Laufer, 2019; Koonin, 2020). This is represented and demonstrated in the diagram below: 
The 4 Key RCRS Cs

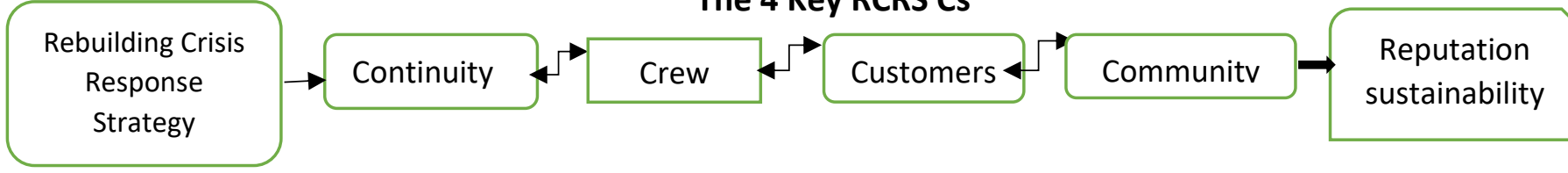

Figure 2: identified four (the $4 \mathrm{Cs}$ ) important domains for Rebuilding Crisis Response Strategies (RCRS)

\section{Protecting Organizational Continuity}

The most recent survey revealed that pandemics crises were not listed among the top risk for Nigeria public university operations that universities should worry about (Kelly 2001; Katjavivi, \& Otaala, 2003; Koonin, 2020). When a crisis hits, the goal of every crisis management is to create an atmosphere for smooth organizational continuity during and after the crisis. This is achievable via appropriate crisis communication response strategies. The resultant effect of crisis communication is dependent on its ability to dialogue with the relevant stakeholders (both in words and actions) using various appropriate response strategies, with the objectives of maintaining reputational capital, keeping stakeholders on track, and allowing organizational continuity during and after the crisis (Kim, Kang, Lee, \& Yang, 2019). Thus, an integral part of crisis management lies in the crisis communication frame used to protect organizational reputation, paving ways for smooth organizational continuity during a crisis. When an organization lost its reputational capital and stakeholders' relationships because of the wrong crisis response strategy employed, there are potential possibilities for business extinction.

However, In the Nigeria context, having examined the numerous threats associated with university reputation as a result of pandemic and none-pandemic crises, the best possible pandemic crisis response strategy is RCRS. This strategy places the publics' interest first, then maintains reputation, instead of denying or bolstering or just diminishing strategies. Caring for stakeholders during a pandemic crisis is essential in developing and underdeveloped countries. This will create an atmosphere where the organization will gain confidence and trust from the public thus, strengthening its reputation and paving opportunities for operational continuity. However, this could be in the form of school fee reduction, provision of safety measures, and relevant and accurate information. It is a combination of words and actions. The RCRS operates in words (communication), and in-kind which is the positive action taken by the organization to restore conducive working environments (Seeger \& Ulmer, 2002; Ou, \& Wong, 2020; Kriyantono \& McKenna, 2019). The pandemic mitigation and best response strategies recommended for Nigeria public universities continuity during a pandemic crisis is RCRS, considering its relevancies both in communication and actions.

\section{Protecting Crew (university workforce)}

During a pandemic crisis, employees are on the front lines and should not be forgotten (Voorhees et al., 2020). Having looked at organizational continuity, it is essential for university organizations to consider their workforce during a pandemic crisis. In planning for pandemic crisis response strategies without placing staff's safety at top priority, there will be no organizational functionality, performativity, and continuity. RCRS allows crucial planning actions for protecting employees' interests during a pandemic crisis. Unlike other strategies: diminishing, bolstering, and denying, which are only limited to words and levels of convictions (Coombs, 2007). Importantly, during a pandemic crisis, actions are more necessary than 
words. It is paramount to identify and allow sick workers to stay at home until full recovery with care and compensation. Apart from physical distancing among staff in the workforce, university organizations should be prepared to provide employee assistance, aid staff vaccination, and maintain the free flow of communication. This is, however, missing among Nigeria public universities during the Covid-19 pandemic crisis (Abugre, 2018; Nwagwu, 2020).

The choice of pandemic crisis response strategies employed to protect university reputation has a significant impact on the students' trust in their respective selections of universities. University organizations contribute to employees' psychological capital by adopting the right pandemic response strategies that put workers' interest top priority (Coombs, 2007; Coombs, 2017; Park, 2017; Crijns et al., 2017; Coombs, Holladay \& White, 2020).

\section{Protecting Customers' Interest (Stakeholders)}

Stakeholders represent any group that can affect or be affected by the decisions, behavior, and response of an organization (Coombs, 2007). The continuity of every university during and after a severe pandemic crisis is heavily dependent on its relevant stakeholders. No organization operates by itself. Therefore, stakeholders play a crucial role in accepting or rejecting the pandemic crisis response employed by organizations. The rejection of a response strategy by stakeholders leads to negative perceptions and eventually generates a threat to organizational reputation. Therefore, during a pandemic crisis, universities need an accommodative response strategy that has the potential of building up some goodwill that can guarantee long-term relationships with stakeholders and protect university reputations (Ratten, 2020). However, RCRS was perceived to be the best in meeting stakeholders' expectations, regaining customers' interest, and protect reputation during a severe pandemic crisis, not minding who is responsible for the crisis. This is because stakeholders only want to see positive actions taken by the organization to protect their interests (Im, Youk, \& Park, 2021).

During a pandemic crisis, RCRS allows an alternative system of procedures in the discharge and delivery of university services: the establishment of an emergency communications plan, creating an avenue to reduce close contact between the two groups (employees and stakeholders or customers), develop alternative approaches in using social media educating platforms to manage, message, signage and to educate customers on pandemic safety procedures, encouragements, and provisions of vaccination procedures (if available) to the staff, students-stakeholders, contingencies and care for sick customers by asking sick stakeholders not to enter the school environment, advancement of quick and ready respond to customers and meeting their expectation, provision of easy alternative university customers care services and reaching to relevant stakeholders' need relating to services delivery. During a pandemic crisis, these plans need to be put in place by the university organizations to protect reputation, regain stakeholders' confidence and maintain customers' expectations. According to SCCT, RCRS meets stakeholders' needs and regains customers' trust, minimizes the seriousness of the pandemic on stakeholders, and protects university reputation (Ou \& Wong, 2020; Kriyantono, \& McKenna, 2019).

Again, to protect customers and employees during a pandemic crisis using RCRS, university organizations can also make provisions for tissues and hand sanitizers, customized face masks for stakeholders use, addressing security and safety issues thus, maintaining order in the university setting. Students need to feel confident that they can enter the university environment and place absolute trust in the university's pandemic crisis response framework. 
This will cement reputational sustainability and generate positive perceptions. A study in Zambia showed that university education is the foundation for national development and effective human capital. It is, therefore, important for Nigeria Public Universities to have the right pandemic crisis response strategies in place to protect the reputation and guarantee continuity (Mwiya, Siachinji, et al., 2019). Consequently, taking care of stakeholders' needs and expectations is the most important factor for reputational sustainability and organizational performative continuity during a pandemic crisis (Qiu, Jiang, et al., 2021).

\section{Rebuilding and engaging with Local Community}

Whatever crises that affect the community equally pose a threat to organizational reputation and performativity within the same community. In managing pandemic crises, university organizations should not underestimate the role and relevance of the geographical community in which it is established. Therefore, in examining the university pandemic response framework, a pandemic crisis response strategy that can foster and strengthen relationships between university organizations and the community should be deemed appropriate.

In this review context, the local community covers a series of pandemic response activities at the community level, aimed at bringing an expected improvement in the social well-being of individuals, groups, and neighborhoods. It is a function of strategizing within a university's defined geographical location, sharing collaborative pandemic plans, solution experiences, concerns, and remedies to the pandemic situation. During a pandemic crisis, the relationships between the university and the local community should be a system of the democratic instrument towards creating a sustainable social change, best health solution options, and well-being among university staff, stakeholders, and the inhabitants of the community (Ross, \& Lappin, 1967; Sheth, 2020). Therefore, it necessitates both university organizations and the local community to identify needs and take actions, thereby, developing cooperative attitudes and prevention practices towards fighting pandemic or epidemic crises (Van den Broucke, 2020).

However, RCRS allows connectivity between the corporate organizations (Nigeria public university organizations) and the local community Public Health and Emergency Management in combating the pandemic crisis, identification of credible channels of local information (where there are none-availability of electricity for television/radio and social media communication platform) and exploring access to local community resources for effective response strategy and university reputation recovery. Any violation between the (university) organizations and local community or the government will generate more crisis. Thus, pandemics have a potential impact on both organizations and communities in terms of reputation, economy, health, education, and human existence at large (Awofeso, \& Irabor, 2020). When responding to pandemics and epidemics crises, sentiments, racial, ethnic, tribal, and religious discriminations should be avoided, to enhance effective results. These four identified domains for RCRS during a pandemic crisis will help sustain Nigerian public university reputation and guarantee stakeholders' relationships.

\section{Reputation in University Organizations}

Just as corporate organizations cannot effectively exist in a competitively driven work environment without a positive reputation, so are university institutions during a pandemic crisis. Reputation in the university, is an aggregate evaluation that university stakeholders 
make in respect of how well the university is meeting stakeholder's expectations and needs, based on its past (crisis) behaviors, performativity, and positive operational consistencies, especially during a current challenging exigency (Coombs, 2007). Nigeria Public universities are no longer immune to the pandemic crisis; therefore, they are not untouchable organizations that could assume societal trust during a tinderbox without their crisis response strategies being questioned. Stakeholders are most concerned about the efforts put in by universities to protect their interests during a pandemic crisis. A pandemic crisis is never an avenue for exploitation but collaborative efforts towards finding a lasting solution and sustaining a reputation (Vercic, \& Znidar, 2016).

Reputation is an essential ingredient and influences confidence for university survival coupled with the effective response strategies employed during severe pandemic crises (Del-CastilloFeito et al., 2020).

However, in the assessment of a university system, reputation stands as a sign of quality that influences stakeholders' loyalty and decisions making (DiStaso, Vafeiadis, \& Amaral, 2015; Busuioc, \& Rimkutè, 2020). Moreover, Universities operate in an elevated complex environment, competing for prestigious competent employees, talented students turn-outs marketization, economic resources from government, and meeting stakeholders' expectations. Therefore, reputation serves as a bedrock in sustaining universities during crises (Christensen, \& Gornitzka, 2017; Hemsley et al., 2016). Again, reputation is the university publics' positive perception that ensures operational continuity, despite the gravity of the challenging situations. It represents a positive ideology an individual stakeholder has towards the university in times of crisis (Duarte et al., 2010; Arpan et al., 2003; Del-Castillo-Feito et al., 2019).

Consequently, in the development of distinctive university identity and excellent performativity, reputation becomes increasingly crucial among university organizations (Hemsley et al., 2016; Busuioc \& Rimkutè, 2020). Despite the impact of reputation on the university, it is not static. Therefore, it can be gained or lost during a pandemic crisis situation (Busuioc, \& Rimkute, 2020). Empirically, now is the time to investigate and refresh the drought of effective pandemic crisis response strategy among public universities in Nigeria and protect its reputation (Kelly, 2001: Katjavivi, et al., 2003: Gainey, 2010: Koonin, L. M. (2020; Shamir, Krauss, et al., 2021).

Reputation in the universities remains a valuable, intangible asset, which attracts students, improve university financial performance, generate investment interest, attract talented top employees, impact positive competitive advantage and embrace positive perceptions from the public (Carmeli, \&Tishler, 2005; Fombrun, \& van Riel,2004; Coombs, 2007; Coombs, Holladay, \& White, 2020).

The literature revealed that the university's reputation experienced a significant threat globally due to pandemic crises (Tesar, 2020; Mok, Xiong, \& Cheung, 2021). in connection with the above findings, Nigerian universities suffer most in terms of reputational threats associated with pandemic crises (Samuel, 2020). A study conducted by Im, Youk \& Park (2021) evident that RCRS was perceived to be best and most appropriate in meeting expectations and guaranteed reputational sustainability during severe crises irrespective of who is responsible for the crisis. 


\section{Methodology}

The authors employed a scoping review of studies on pandemic crises, rebuilding crises response strategies (RCRS), and university reputation sustainability during the Covid-19 pandemic crisis or other related emergencies involving infectious diseases. Scoping reviews are usually used for studies related to disaster response and preparedness (Riccardo et al., 2018; Wilson et al., 2012). However, even though we did not use meta-analysis in the review, systematic review methods were employed to minimize bias that might arise from the identification and inclusion of the study (Daudt et al., 2013). Google scholar search was used throughout the study. Google scholar has the largest coverage of literature and the most comprehensive academic search engine, found in academic search engines and bibliographic databases (ASEBDs), with the Inclusion of subscription-based SCOPUS, ERA, and Web of Science databases (Lo'pez-Co'zar et al., 2019; Gusenbauer, 2019; Martin-Martin et al., 2017). Most importantly, this review paper was on the synthesis of university covid-19 related news, supported by relevant literature review on Covid-19 and university reputation, and the strength of Situational Crisis Communication Theory's (SCCT) rebuilding response strategies. The authors' personal experiences in investigating pandemic crises and university reputation sustainability also contributed to the study. From the initial search, the resulting papers were first assessed for relevance purposes. Thereafter, the relevant articles were evaluated based on their titles. Studies that were not relevant to the review topic were omitted (Coombs, 2007; Fakoya, McCorry, \& Donnelly, 2020).

\section{Conclusion and Suggestions}

Covid-19 has a long-term impact on university reputation globally. This perspective article takes the Nigeria universities as a case in point to discuss the protective power of rebuilding crisis response strategies among Nigeria university institutions and its reputation Sustainability during and after the Covid-19 Pandemic Crisis. With the significant impacts of the pandemic crisis outbreak, this article provides key insights to help university practitioners and policy-makers develop specific effective pandemic response strategies in other to boost stakeholders' confidence and maintain a good reputation during public health crises (figure 1). This article tends to fill the gap in the crisis communication domain concerning a dearth of information on the university's pandemic crisis response strategies. Scholars found that the outbreak of the recent Covid-19 crisis exposed this deficiency as universities globally experienced reputational shifts. Based on the variables posited in Coombs (2007) Situational Crisis Communication Theory SCCT and this review article (Rebuilding Crisis Response Strategies: Nigerian University Reputation Sustainability during and after the Covid-19 Pandemic Crisis), rebuilding response strategy was predicted as appropriate in sustaining reputation during a pandemic crisis.

From the review of relevant literature, the prediction of RCRS was made for university reputation sustainability during a pandemic crisis, based on its protective strength in response (communication) and actions (kindness and compensation). The pandemic crisis posed a potential threat to the university's reputation and attracted negative public perceptions. Rebuilding crisis response strategies rebuild stakeholders' relationships, generate positive public perceptions, and sustain reputation during a pandemic crisis. This predicted approach is what is expected of universities facing reputational damage during a pandemic crisis.

Again, the review identified four (the 4 Cs) important domains for Rebuilding Crisis Response Strategies (RCRS) planning among universities facing a pandemic crisis as COVID-19: continuity, crew, customers, and community. These domains are significant in mitigating any 
pandemic severity, protect organizational continuity and guarantee reputational sustainability during pandemic crises among universities.

Theoretically, the authors employed a scoping review of studies on pandemic crises, rebuilding crisis response strategies (RCRS), and university reputation sustainability during epidemics crises or related emergencies involving infectious diseases. However, we did not use meta-analysis in the review. The application of systematic review methods minimizes bias that might arise from the identification and inclusion of the studies. Therefore, future studies are recommended to use meta-analysis for results consistency in respect to finding a solution to university pandemic crisis response strategies, which is lacking in the crisis communication literature. Additionally, it is recommended that other prospective scholars should consider conducting quantitative or qualitative studies towards exploring the best possible pandemic crisis response strategies among universities and how reputation might be enhanced and sustained during a pandemic crisis.

Significantly, the findings from this review aroused the awareness of the public universities' pandemic crisis response strategies in the Nigeria context, promoting the role of rebuilding crisis response strategies during a pandemic crisis and possibly deal with the info-demic that comes with it. Thus, providing valuable information on corporate organization's perception of COVID-19 pandemic crisis response strategies and how it affects academics' reputation. This review served as a subsequent reference point for Nigeria public universities and other global universities on pandemic crisis response strategies and reputational sustainability during the future emergence of the pandemic crisis.

\section{Situational Crisis Communication Theory (SCCT)}

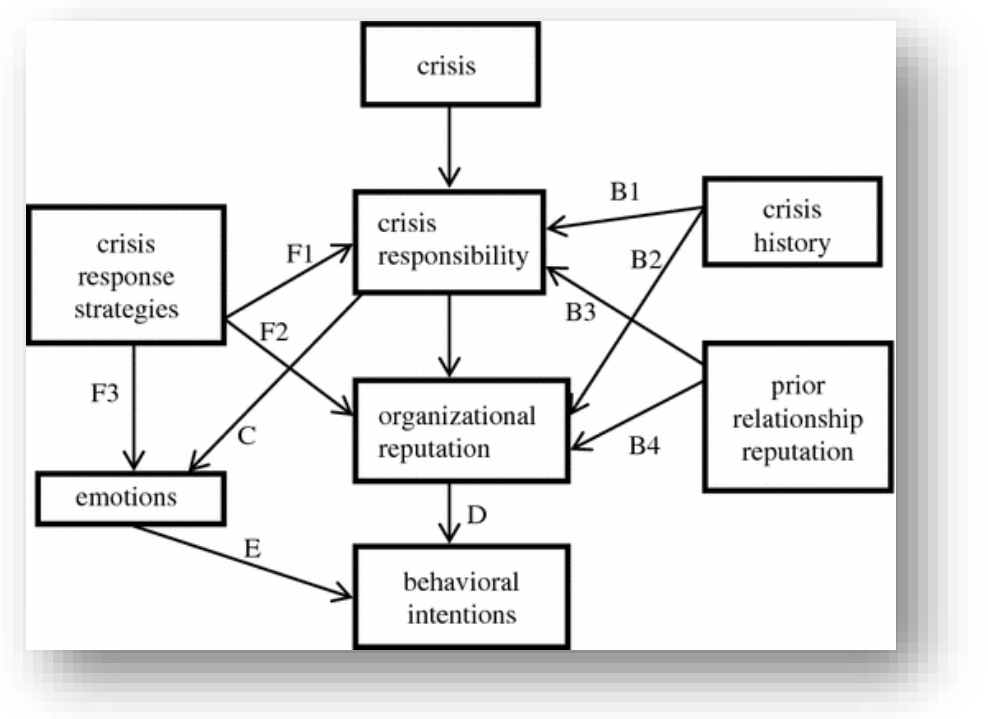

Figure 3: Situational crisis communication theory (Coombs, 2007) 


\section{Crisis Response Strategies}

SCCT's rebuilding response strategies concepts

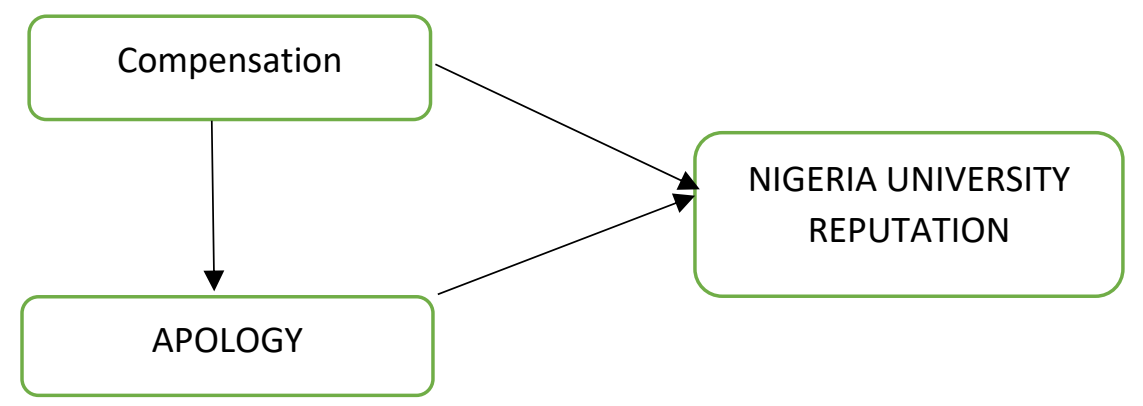

Figure 4: The review framework based on established SCCT.

\section{References}

Aborode, A., Anifowoshe, O., Ayodele, T. I., Iretiayo, A. R., \& David, O. O. (2020). Impact of COVID-19 on Education in Sub-Saharan Africa.

Abugre, J. B. (2018). Institutional governance and management systems in Sub-Saharan Africa higher education: developments and challenges in a Ghanaian Research University. Higher Education, 75(2), 323-339.

Akan, H., Gurol, Y., Izbirak, G., Ozdatlı, S., Yilmaz, G., Vitrinel, A., \& Hayran, O. (2010). Knowledge and attitudes of university students toward pandemic influenza: a crosssectional study from Turkey. BMC Public health, 10(1), 1-8.

Aladwan, S. A., \& Alshami, S. I. (2021). The impact of service excellence and service innovation on organisational reputation: quantitative evidence from Jordanian public sector. The TQM Journal

Aladwan, S. A., \& Alshami, S. I. (2021). The impact of service excellence and service innovation on organisational reputation: quantitative evidence from Jordanian public sector. The TQM Journal.

Arinaminpathy, N., Raphaely, N., Saldana, L., Hodgekiss, C., Dandridge, J., Knox, K., \& McCarthy, N. D. (2012). Transmission and control in an institutional pandemic influenza A (H1N1) 2009 outbreak. Epidemiology \& Infection, 140(6), 1102-1110.

Arpan, L. M., Raney, A. A., \& Zivnuska, S. (2003). A cognitive approach to understanding university image. Corporate communications: An international journal.

Awofeso, O., \& Irabor, P. A. (2020). Assessment of Government Response to Socioeconomic Impact of Covid-19 Pandemic in Nigeria. Journal of Social and Political Sciences, 3(3).

Beaton, R., Stergachis, A., Thompson, J., Osaki, C., Johnson, C., Charvat, S. J., \& MarsdenHaug, N. (2007). Pandemic policy and planning considerations for universities: findings from a tabletop exercise. Biosecurity and Bioterrorism: Biodefense strategy, practice, and science, 5(4), 327-334.

Carmeli, A., and Tishler, A. (2005) 'Perceived organizational reputation and organizational performance: An empirical investigation of industrial enterprises', Corporate Reputation Review, 8 (1), 13-30.

Choi, J. S., \& Yang, N. Y. (2010). Perceived knowledge, attitude, and compliance with preventive behavior on influenza A (H1N1) by university students. Korean Journal of Adult Nursing, 22(3), 250-259. 
Christensen, T., \& Gornitzka, Å. (2017). Reputation management in complex environmentsA comparative study of university organizations. Higher Education Policy, 30(1), 123140.

Chukwuorji, J. C., \& lorfa, S. K. (2020). Commentary on the coronavirus pandemic: Nigeria. Psychological Trauma: Theory, Research, Practice, and Policy, 12(S1), S188.

Coombs, W. T. (2007). Protecting organization reputations during a crisis: The development and application of situational crisis communication theory. Corporate reputation review, 10(3), 163-176.

Coombs, W. T. (2017). Revising situational crisis communication theory. Social media and crisis communication, 1, 21-37.

Coombs, W. T., Holladay, S. J., \& White, K. L. (2020). 11 Situational Crisis Communication Theory (SCCT) and Application in Dealing with Complex, Challenging, and Recurring Crises. Advancing Crisis Communication Effectiveness: Integrating Public Relations Scholarship with Practice, 15.

Crijns, H., Claeys, A. S., Cauberghe, V., \& Hudders, L. (2017). Who says what during crises? A study about the interplay between gender similarity with the spokesperson and crisis response strategy. Journal of Business Research, 79, 143-151.

Daudt, H. M., van Mossel, C., \& Scott, S. J. (2013). Enhancing the scoping study methodology: a large, inter-professional team's experience with Arksey and O'Malley's framework. BMC medical research methodology, 13(1), 1-9.

Del-Castillo-Feito, C., Blanco-González, A., \& Delgado-Alemany, R. (2020). The relationship between image, legitimacy, and reputation as a sustainable strategy: Students' versus professors' perceptions in the higher education sector. Sustainability, 12(3), 1189.

Del-Castillo-Feito, C., Blanco-González, A., \& González-Vázquez, E. (2019). The relationship between image and reputation in the Spanish public university. European Research on Management and Business Economics, 25(2), 87-92.

DiStaso, M. W., Vafeiadis, M., \& Amaral, C. (2015). Managing a health crisis on Facebook: How the response strategies of apology, sympathy, and information influence public relations. Public Relations Review, 41(2), 222-231.

Dobrowolski, Z. (2020). After COVID-19: reorientation of crisis management in crisis. Entrepreneurship and Sustainability Issues, 8(2).

Dowling, G. (2006). How good corporate reputations create corporate value. Corporate Reputation Review, 9(2), 134-143.

Duarte, P. O., Alves, H. B., \& Raposo, M. B. (2010). Understanding university image: a structural equation model approach. International review on public and nonprofit marketing, 7(1), 21-36.

Etokidem, A. J., Ago, B. U., Mgbekem, M., Etim, A., Usoroh, E., \& Isika, A. (2018). Ebola virus disease: assessment of knowledge, attitude and practice of nursing students of a Nigerian University. African health sciences, 18(1), 55-65.

Fakoya, O. A., McCorry, N. K., \& Donnelly, M. (2020). Loneliness and social isolation interventions for older adults: a scoping review of reviews. BMC public health, 20(1), 1-14.

Fombrun, C. J., and Van Riel, C. B. M. (2004) Fame \& Fortune: How Successful Companies Build Winning Reputations, Prentice-Hall Financial Times, New York.Return to ref Fombrun and van Riel, 2004 in article 
Gainey, B. S. (2010). Crisis management in public school districts. Organization Development Journal, 28(1), 89.

Gusenbauer, M. (2019). Google Scholar to overshadow them all? Comparing the sizes of 12 academic search engines and bibliographic databases. Scientometrics, 118(1), 177214.

Gwebu, K. L., Wang, J., \& Wang, L. (2018). The role of corporate reputation and crisis response strategies in data breach management. Journal of Management Information Systems, 35(2), 683-714.

Gwebu, K. L., Wang, J., \& Wang, L. (2018). The role of corporate reputation and crisis response strategies in data breach management. Journal of Management Information Systems, 35(2), 683-714.

Hemsley-Brown, J., Melewar, T. C., Nguyen, B., \& Wilson, E. J. (2016). Exploring brand identity, meaning, image, and reputation (BIMIR) in higher education: A special section.

Hemsley-Brown, J., Melewar, T. C., Nguyen, B., \& Wilson, E. J. (2016). Exploring brand identity, meaning, image, and reputation (BIMIR) in higher education: A special section.

Huang, Y., \& DiStaso, M. (2020). Responding to a Health Crisis on Facebook: The Effects of Response Timing and Message Appeal. Public Relations Review, 46(3), 101909.

Huang, Y., \& DiStaso, M. (2020). Responding to a Health Crisis on Facebook: The Effects of Response Timing and Message Appeal. Public Relations Review, 46(3), 101909.

Ilesanmi, O., \& Afolabi, A. (2020). Time to move from vertical to horizontal approach in our COVID-19 response in Nigeria. SciMedicine Journal, 2, 28-29.

Im, W. J., Youk, S., \& Park, H. S. (2021). Apologies combined with other crisis response strategies: Do the fulfillment of individuals' needs to be heard and the timing of response message affect apology appropriateness?. Public Relations Review, 47(1), 102002

Jacob, O. N., Abigeal, I., \& Lydia, A. E. (2020). Impact of COVID-19 on the higher institutions development in Nigeria. Electronic Research Journal of Social Sciences and Humanities, 2(2), 126-135.

Jain, R., Budlender, J., Zizzamia, R., \& Bassier, I. (2020). The labor market and poverty impacts of covid-19 in South Africa.

Kamal, N. N., \& Seedhom, A. E. (2011). Knowledge, attitude and practice of El-Minia university students towards pandemic H1N1, Egypt, 2009. Journal of Public Health, 19(6), 505-510.

Katjavivi, P. H., \& Otaala, B. (2003). African higher education institutions responding to the HIV/AIDS pandemic. In AAU conference of Rectors, Chancellors and Presidents of African Universities. Mauritius.

Kelly, M. J. (2001). Challenging the Challenger: Understanding and expanding the response of Universities in Africa to HIV/AIDS. In African Symposium: An On-Line African Educational Research Journal (Vol. 1, No. 3).

Kiambi, D. M., \& Shafer, A. (2016). Corporate crisis communication: Examining the interplay of reputation and crisis response strategies. Mass Communication and Society, 19(2), 127-148.

Kiambi, D. M., \& Shafer, A. (2016). Corporate crisis communication: Examining the interplay of reputation and crisis response strategies. Mass Communication and Society, 19(2), 127-148. 
Kim, E., Kim, T., \& Rhee, M. (2021). The dynamics of organizational reputation and status: momentum and volatility. Management Decision.

Kim, Y., Kang, M., Lee, E., \& Yang, S. U. (2019). Exploring crisis communication in the internal context of an organization: Examining moderated and mediated effects of employeeorganization relationships on crisis outcomes. Public Relations Review, 45(3), 101777.

Koonin, L. M. (2020). Novel coronavirus disease (COVID-19) outbreak: Now is the time to refresh pandemic plans. Journal of business continuity \& emergency planning, 13(4), 1-15.

Kriyantono, R., \& McKenna, B. (2019). Crisis response vs crisis cluster: A test of situational crisis communication theory on crisis with two crisis clusters in Indonesian Public Relations. Jurnal Komunikasi: Malaysian Journal of Communication, 35(1).

Li, Q., Wei, H., \& Laufer, D. (2019). How to make an industry sustainable during an industry product harm crisis: The role of a consumer's sense of control. Sustainability, 11(11), 3016.

Lopez-Cozar, E. D., Orduña-Malea, E. and Martín-Martín, A. (2019) 'Google Scholar as a data source for research assessment." In Springer handbook of science and technology indicators (pp. 95-127). Springer, Cham.

Madhav, N., Oppenheim, B., Gallivan, M., Mulembakani, P., Rubin, E., \& Wolfe, N. (2017). Pandemics: risks, impacts, and mitigation.

Martel, M. (2020). COVID-19 EFFECTS ON US HIGHER EDUCATION CAMPUSES. From Emergency Response to Planning for Future Student Mobility. Institute of International Education.

Martín-Martín, A., Orduña-Malea, E., Harzing, A. W., \& Lopez-Cozar, E. D. (2017). Can we use Google Scholar to identify highly-cited documents?. Journal of informetrics, 11(1), 152-163.

Mercado, S. (2020). International student mobility and the impact of the pandemic. BizEd: AACSB International, 11.

Mok, K. H., Xiong, W., Ke, G., \& Cheung, J. O. W. (2021). Impact of COVID-19 pandemic on international higher education and student mobility: Student perspectives from mainland China and Hong Kong. International Journal of Educational Research, 105, 101718.

Mwiya, B., Siachinji, B., Bwalya, J., Sikombe, S., Chawala, M., Chanda, H., ... \& Kaulungombe, B. (2019). Are there study mode differences in perceptions of university education service quality? Evidence from Zambia. Cogent Business \& Management, 6(1), 1579414.

Nwagwu, W. E. (2020). E-learning readiness of universities in Nigeria-what are the opinions of the academic staff of Nigeria's premier university?. Education and Information Technologies, 25(2), 1343-1370.

Ou, J., \& Wong, I. A. (2020). Strategic crisis response through changing message frames: a case of airline corporations. Current Issues in Tourism, 1-15.

Oyediran, W. O., Omoare, A. M., Owoyemi, M. A., Adejobi, A. O., \& Fasasi, R. B. (2020). Prospects and limitations of e-learning application in private tertiary institutions amidst COVID-19 lockdown in Nigeria. Heliyon, 6(11), e05457.

Ozili, P. K., \& Arun, T. (2020). Spillover of COVID-19: impact on the Global Economy. Available at SSRN 3562570. 
Ozili, P. K., \& Arun, T. (2020). Spillover of COVID-19: impact on the Global Economy. Available at SSRN 3562570.

Park, H. (2017). Exploring effective crisis response strategies. Public Relations Review, 43(1), 190-192.

Qiu, S. C., Jiang, J., Liu, X., Chen, M. H., \& Yuan, X. (2021). Can corporate social responsibility protect firm value during the COVID-19 pandemic? International Journal of Hospitality Management, 93, 102759.

Randiek, K. (2019). Role of Online Crisis Response Strategies on Organizational Reputation at Kenya Power and Lighting Company (Doctoral dissertation, United States International University-Africa).

Randiek, K. (2019). Role of Online Crisis Response Strategies on Organizational Reputation at Kenya Power and Lighting Company (Doctoral dissertation, United States International University-Africa).

Ratten, V. (2020). Coronavirus (Covid-19) and the entrepreneurship education community. Journal of Enterprising Communities: People and Places in the Global Economy.

Reperant, L. A., \& Osterhaus, A. D. (2017). AIDS, Avian flu, SARS, MERS, Ebola, Zika... what next?. Vaccine, 35(35), 4470-4474.

Riccardo, F., Suk, J. E., Espinosa, L., Bella, A., Giambi, C., Del Manso, M., ... \& Declich, S. (2018). Key dimensions for the prevention and control of communicable diseases in institutional settings: a scoping review to guide the development of a tool to strengthen preparedness at migrant holding centres in the EU/EEA. International journal of environmental research and public health, 15(6), 1120.

Ross, M. G., \& Lappin, B. W. (1967). Community organization; theory, principles, and practice. New York: Harper \& Row.

Salman, M., Shehzadi, N., Hussain, K., Saleem, F., Khan, M. T., Asif, N., ... \& Sulaiman, S. A. S. (2017). Knowledge of Ebola virus disease among a university population: A crosssectional study. American journal of infection control, 45(2), e23-e25.

Samuel, A. I. (2020). Coronavirus (COVID-19) and Nigerian Education System: Impacts, Management, Responses, and Way Forward. Education Journal, 3(4), 101-102.

Schoofs, L., Claeys, A. S., De Waele, A., \& Cauberghe, V. (2019). The role of empathy in crisis communication: Providing a deeper understanding of how organizational crises and crisis communication affect reputation. Public Relations Review, 45(5), 101851.

Seale, H., Mak, J. P., Razee, H., \& Maclntyre, C. R. (2012). Examining the knowledge, attitudes and practices of domestic and international university students towards seasonal and pandemic influenza. BMC Public Health, 12(1), 1-6.

Seeger, M., \& Ulmer, R. (2002). A post-crisis discourse of renewal: The cases of Malden Mills and Cole Hardwoods. Journal of Applied Communication Research, 30(2), 126-142.

Setiawan, A. R. (2020). Scientific literacy worksheets for distance learning in the topic of Coronavirus 2019 (COVID-19). EdArXiv. DOI: https://doi. org/10.35542/osf. io/swjmk.

Shamsir, M. S., Krauss, S. E., Ismail, I. A., Ab Jalil, H., Johar, M. A., \& Rahman, I. A. (2021). Development of a Haddon Matrix Framework for Higher Education Pandemic Preparedness: Scoping Review and Experiences of Malaysian Universities During the COVID-19 Pandemic. Higher Education Policy, 1-40.

Sheth, J. (2020). Business of business is more than business: Managing during the Covid crisis. Industrial Marketing Management, 88, 261-264.

Sundarasen, S., Chinna, K., Kamaludin, K., Nurunnabi, M., Baloch, G. M., Khoshaim, H. B., ... \& Sukayt, A. (2020). Psychological impact of COVID-19 and lockdown among 
university students in Malaysia: Implications and policy recommendations. International journal of environmental research and public health, 17(17), 6206.

Suresh, P. S., Thejaswini, V., \& Rajan, T. (2011). Factors associated with 2009 pandemic influenza $A(H 1 N 1)$ vaccination acceptance among university students from India during the post-pandemic phase. BMC Infectious Diseases, 11(1), 1-8.

Surgeoner, B. V., Chapman, B. J., \& Powell, D. A. (2009). University students' hand hygiene practice during a gastrointestinal outbreak in residence: what they say they do and what they actually do. Journal of environmental health, 72(2), 24-29.

Tesar, M. (2020). Towards a post-Covid-19 'new normality?': Physical and social distancing, the move to online and higher education.

Tesar, M. (2020). Towards a post-Covid-19 'new normality?': Physical and social distancing, the move to online and higher education.

Tork, H. M., \& Mersal, F. A. (2018). Middle East respiratory syndrome-corona virus: knowledge and attitude of Qassim University students, KSA. Global Adv Res J Med Med Sci, 7(4), 90-7.

Uchida, M., Tsukahara, T., Kaneko, M., Washizuka, S., \& Kawa, S. (2012). How the H1N1 influenza epidemic spread among university students in Japan: experience from Shinshu University. American journal of infection control, 40(3), 218-220.

Van den Broucke, S. (2020). Why health promotion matters to the COVID-19 pandemic, and vice versa.

Vercic, A. T., Vercic, D., \& Znidar, K. (2016). Exploring academic reputation-is it a multidimensional construct? Corporate Communications: An International Journal.

Voorhees, C. M., Fombelle, P. W., \& Bone, S. A. (2020). Don't Forget about the frontline employee during the COVID-19 pandemic: Preliminary insights and a research Agenda on Market Shocks.

Wilson, M. G., Lavis, J. N., \& Guta, A. (2012). Community-based organizations in the health sector: a scoping review. Health research policy and systems, 10(1), 1-9.

Ye, L., \& Ki, E. J. (2017). Organizational crisis communication on Facebook. Corporate Communications: An International Journal.

Yu, I. T., Li, Y., Wong, T. W., Tam, W., Chan, A. T., Lee, J. H., ... \& Ho, T. (2004). Evidence of airborne transmission of the severe acute respiratory syndrome virus. New England Journal of Medicine, 350(17), 1731-1739.

Zhang, Y. Z., Zhang, F. X., Gao, N., Wang, J. B., Zhao, Z. W., Li, M. H., ... \& Plyusnin, A. (2009). Hantaviruses in rodents and humans, inner Mongolia Autonomous region, China. Emerging infectious diseases, 15(6), 885. 